\title{
2-2-9Ｋotz人工関節置換症例における 術後X線変化の検討
}

\author{
熊本大学 整形外科 \\ ○薬師寺俊剛 (やくしじとしたけ)，米村憲輔，西田公明， \\ 加藤悌二，梅村武寛，高木克公
}

【目的】Kot 2 人工関節置換術施行症例における術後X線変化について、使用機種別の比較検 討を行ったので報告する。

【方法】過去 10 年間にKot $\mathrm{z}$ 人工関節置換術を施行した 24 例 (男性·女性ともに 12 例、平均年 齢46.3歳、KMFTR10例、HMRS14例)に対し、X線上アンカー部のbone remodellingならびに固 定性、骨・ステム間のradiolucent 1 ineをRizzoli grading systemもしくはISOLS systemを 用い評価した。

【結果】最終経過観察時 (平均28.0ケ月)、bone remodellingにおいてstableな状態を呈し た症例は旧型のKMFTRで多いものの、固定性に関しては両機種間で差を認めなかった。ま

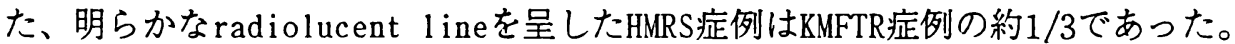

【考察】改良型であるHMRSが従来のKMFTRに比べ、X線学的評価上著明に改善されたとは判 断し難く、今後症例数ならびに経過観察期間の増加に伴う再評価が必要であると考える。

\section{2-2-10 PBSCT 併用大量化学療法を行った}

\section{腸骨ユーイング肉腫の治療経験}

国立小倉病院 整形外科

○高比良知也（たかひらともなり）、横山庫一郎、浦田正彦、 古賀正一郎、佐々峵介、芳賀敏

【はじめに】腸骨発生のユーイング肉腫は予後が不良であり、近年その治療にPBSCT 併用 大量化学療法が試みられている。我々もその治療を経験したのて報告する。

【症例】症例は 13 才男子。平成10年 2 月左殿部痛と発熱を主訴に来院し、生検で左腸骨 ユーイング肉腫と診断された。当初外科的切除をする予定で術前療法としてVAIA による 化学療法、放射線療法 30Gy を行った。その後、頭部、肺、反対側腸骨への転移が疑われ たため、5 月10日よりCABG、Ifomide、VP-16によるPBSCT 併用大量化学療法を試み 経過をみていたところ 7 月 10 日頃より再び発熱、左股関節痛が出現してきた。腸骨再燃と 判断し再度VAIA 療法を開始したところ化療終了後より直ちに解熱し疼痛も消失した。

【考察】化学療法、放射線療法による画像所見の変化を供覧し、経過を報告し、PBSCT 併用療法の問題点につき考察した。 
$2-2-11$

\author{
婹椎、仙骨に発生した \\ Polyostotic fibrous dysplasiaの手術治茗経踔
}

社会保険 小倉記念病院 整形外科

○藤尾圭司、山中三知夫、土屋隆之、小田祐造、岩瀬丈明

【目的】Polyostotic fibrous dysplasiaの冷椎発生例の報告は少なく、また手術の報告例は 非常に少ない。今回我々は脊椎（腰椎、仙骨）、助骨、頭蓋骨に発生したfibrous dysplasia で腰椎、仙骨病变が大きく、病的骨折を起こす可能性が高いと判断し、手術を行った症例 の治嚗経験を報告する。

【症例】 25 藏、男性。2年間保存的に経過観察を行ったが腰痛か悪化し、平成9年6月13日 手術を行った。仙骨に対して病巣を搔爬、欠損部にA-W glass ceramicsを充填した。第2 腰椎に対しては病巣掻爬、腸骨からの全層骨移植とともに上下椎体にLD anterior spinal

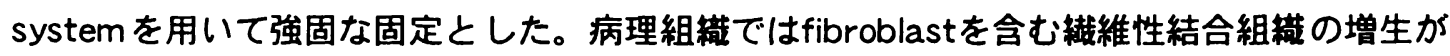
認められ、その中に線維性骨が認められた。以上より診断はfibrous dysplasia ( polyostotic type )と診断された。術後約 1 年現在、仕事に復帰しており、経過良好である。

2-2-12 放射線治療後に発生した仙骨悪性骨巨細胞腫の1例

久留米大学整形外科

○高山純一（たかやまじゅんいち）、小宮節郎、平岡弘二、 濱田哲矢、井上明生

仙骨発生の骨巨細胞腫の治療には難渋することが多いが、今回我々は再発した骨巨細胞腫の 摘出術後に放射線治療を施行し、その7年後に再々発を認悪性化をきたした症例を释験し たので報告する。［症例］34歳 女性1988年1月より腰痛が增強し当科を受診した。諸検 查の結果仙骨の骨巨細胞腫の診断を認め、同年5月腫矈摘出術施行するも1989年11月腫場 の再発を認め再度腫場摘出術を施行した。手術はmarginal marginとなったため術後に50Gy の放射線を照射した。その後腫怚の再発を認めず経過を観察していたが、7年後の1997年3 月に再々発を認めた。腫場は右仙腸関節を越え広範に浸潤していたため、完全摘出は困難と 判断し、病巣怪爬および術中電子線照射を施行した。しかし術後創部感染をきたし病巣择爬 をさらに行ったが、術後摘出標本より悪性化の像を認めた。その後腫撂は增大し1998年6月 不幸な転帰をとった。 